\title{
APPLICATION OF A SCLEROMETER TO THE PRELIMINARY ASSESSMENT OF CONCRETE QUALITY IN STRUCTURES AFTER FIRE
}

\author{
R. KOWALSKI ${ }^{1}$, J. WRÓBLEWSKA ${ }^{2}$
}

\begin{abstract}
The paper presents a description and results of a study focused on the applicability of the sclerometric method to the preliminary assessment of concrete quality in structures after fire. Due to the high thermal inertia, concrete has non-uniform properties in the heated element cross-section. The greatest reduction of concrete compressive strength occurs on the heated surface. When assessing a structure after a fire, it is particularly important to determine the thickness of the damaged external concrete layer. Reinforced concrete beams exposed to high temperature on one side (a one-way heat transfer in the cross-section) for 0 (unheated element), 60, 120, 180 and 240 minutes were examined. A significant decrease of the rebound number on the elements heated surface was observed, depending on the heating duration. The obtained values of the relative rebound number reduction were comparable to the values of relative compressive strength decrease (determined on the basis of temperature) of concrete situated $15 \mathrm{~mm}$ from the heated surface.
\end{abstract}

Keywords: concrete, high temperature, fire, nondestructive test, sclerometer, Schmidt hammer, rebound number

\footnotetext{
${ }^{1}$ DSc., PhD., Eng., Associate professor, Warsaw University of Technology, Faculty of Civil Engineering, ul. Lecha Kaczyńskiego 16, 00-637 Warsaw, Poland, e-mail: r.kowalski@il.pw.edu.pl

${ }^{2}$ MSc., Eng., Warsaw University of Technology, Faculty of Civil Engineering, ul. Lecha Kaczyńskiego 16, 00-637 Warsaw, Poland, e-mail: j.wroblewska@il.pw.edu.pl
} 


\section{INTRODUCTION}

Reinforced concrete structures have relatively good natural fire resistance [1-4]. Concrete in a structure, contrary to steel or timber, usually does not get completely destroyed in fire [5-9]. However, as a result of the exposure to high temperature, a number of thermo-mechanical, physical and chemical processes occur in the structure of concrete, negatively affecting its mechanical properties [1, 10-14]. The decrease of concrete compressive strength in high temperature is particularly important as this may have a significant effect on the reduction of the structural loadbearing capacity. This issue has been studied frequently $[10,15-18]$ and is widely described in the literature, e.g. $[2,3,11,19,20]$. The outcome of the collected experimental results is a generalised, standard [21] relationship between the temperature of concrete $(\theta)$ and the relative decrease of concrete compressive strength $\left(f_{c \theta} / f_{c k}\right.$; see Fig. 10). From a practical point of view, considering the load-bearing capacity of a structure, concrete heated to $500-600^{\circ} \mathrm{C}$ can be regarded as destroyed [3, 22].

Due to the high thermal inertia of concrete, during a fire, the interior of the element cross-section heats up more slowly than the surface [9]. Therefore, the temperature on the element surface is much higher than inside. As a result, the concrete has non-uniform properties in the cross-section. The greatest degradation of concrete, as well as the reduction of its compressive strength, occurs in the near-surface layer. During the assessment of concrete in structures after a fire, it is particularly important to determine the thickness of the external layer of the tested element cross-section, in which the concrete is so damaged that it should be considered as destroyed [4, 5, 7, 23, 24].

The sclerometric method is used for nondestructive testing of concrete in situ and can be applied to indirect estimation of the compressive strength of concrete in structures. Testing concrete with a sclerometer in normal conditions is standardized [25]. A lot of additional information concerning the methodology of the test and experimental relationships for the determination of concrete strength can also be found in [26]. 
The sclerometric test is based on the correlation between the compressive strength of concrete and its surface hardness. After applying a sclerometer (Schmidt hammer) to the element, a spring system releases a hammer mass which strikes a plunger in contact with the concrete surface and then rebounds at a certain distance, known as the rebound number. In [27] two alternative ways of assessing the concrete strength on the basis of rebound number measurements are given. The first one is to establish a direct correlation between the sclerometric test results and the compressive strength of concrete, determined in the destructive test. For this purpose, it is required to examine at least 18 specimens taken from the structure. The second way is based on the predefined relationship between the rebound number and concrete compressive strength [27]. The initial calibration of this relationship shall be performed considering the results of destructive tests on at least 9 core samples. With the use of a sclerometer, it is only possible to determine the compressive strength of concrete in the nearsurface layer with a thickness not exceeding $30 \mathrm{~mm}$ [24]. Concrete in the tested area shall be grinded and cleaned so that the hammer strikes a flat and dry surface [25].

The sclerometric method may also be useful for the assessment of structures after a fire. However, with this method it is only possible to pre-identify areas where the concrete: (1) has been destroyed, (2) has been slightly damaged or (3) has not been significantly affected by the high temperature and is not damaged. It is not possible to fully apply the sclerometric method to the assessment of concrete strength in the structure after a fire. The results of tests on core samples, required to determine the relationship between the rebound number and concrete compressive strength, are then usually unreliable [28] as the concrete has non-uniform properties along the specimen axis.

The paper presents a description and results of a study focused on the applicability of the sclerometric method to the preliminary assessment of concrete quality in structures after fire. Tests were performed on reinforced concrete elements heated in a planned way and then freely cooled in the air. This was to study the rebound number changes with respect to concrete damage caused by a known high temperature field. 


\section{EXPERIMENTAL STUDY}

\subsection{ELEMENTS}

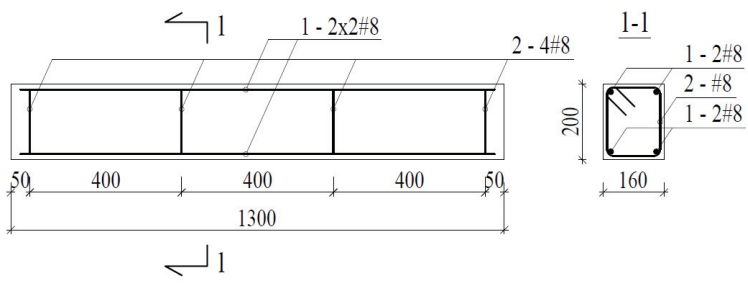

Fig. 1. Beams dimensions and reinforcement

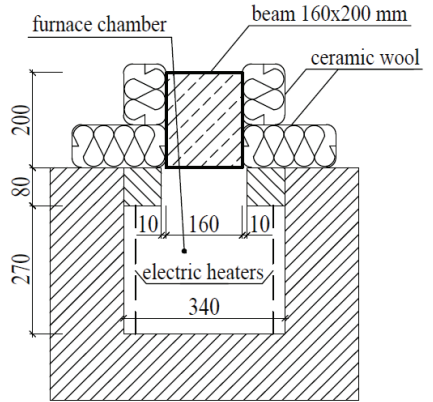

Fig. 2. Beam location in the furnace chamber

Five RC beams $160 \times 200 \mathrm{~mm}$ in cross-section and $1300 \mathrm{~mm}$ in length (Fig. 1), made of C35/45 concrete with gravel (siliceous) aggregate, were examined. The average compressive strength of the concrete determined on $150 \mathrm{~mm}$ cubes was $46.3 \mathrm{MPa}$ after 28 days from casting and $60.8 \mathrm{MPa}$ after 4 months (at that time the elements were heated). To prevent unexpected cracking, the beams were reinforced with $8 \mathrm{~mm}$ diameter bars made of steel with a characteristic yield strength of $500 \mathrm{MPa}$.

\subsection{TESTING PROCEDURE}

The beams were heated for 0 (unheated element), 60,120, 180 or 240 minutes using a heightadjustable electric furnace (Fig. 2), and then were cooled freely in the air. Before the test, the temperature in the furnace chamber reached $450^{\circ} \mathrm{C}$. The furnace was then placed under the beam and heating continued. For about 40 minutes the temperature in the furnace chamber increased to about $900^{\circ} \mathrm{C}$ and was maintained until the end of the test. Immediately after placing the furnace under the beam, ceramic wool insulation was fixed to the element lateral surfaces (Fig. 2). In this way, a oneway heat transfer in the cross-section was provided. The temperature in the furnace chamber, on the beam surface and at selected points inside the cross-section was measured during the test (Fig. 5a). The cooled element was turned upside down. In this way, a good access to the heated surface was provided. Three 100x100 mm locations (Fig. 3a) were then selected; in each of them, ten readings were taken with a Schmidt hammer type N. 
a)

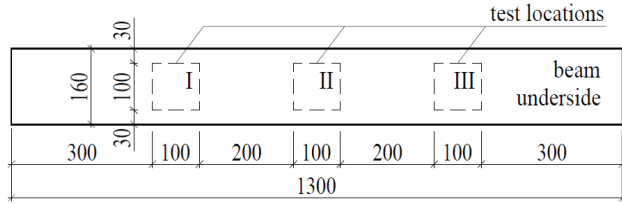

b)

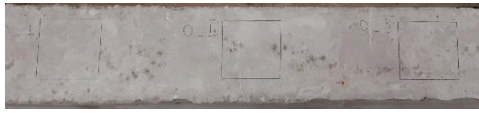

$0 \mathrm{~min}$

c)

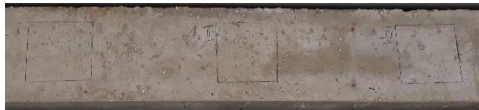

$60 \mathrm{~min}$ d)

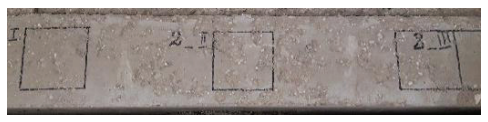

$120 \mathrm{~min}$

e)

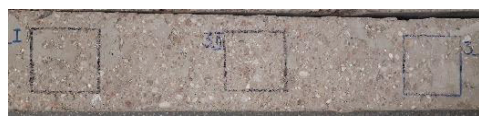

$180 \mathrm{~min}$

f)

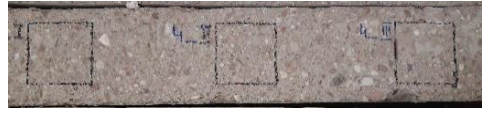

$240 \mathrm{~min}$

Fig. 3. Tested elements: a) sclerometric test locations, b-f) surface of the beam underside after a specified heating duration

Dust and loose pieces of aggregate or cement paste were removed from the marked areas of the tested surface. However, grinding the concrete surface as recommended for testing at ordinary room temperature [25] was abandoned. The surface roughness (caused by the effect of high temperature) was retained to imitate a preliminary, quick test, which could easily be performed on the real structure after a fire. Surface grinding is labour-intensive and would significantly delay the test. And yet, as already stated, the sclerometric method can only be used for the initial identification of areas where concrete has been damaged during a fire. In addition, grinding would remove the most damaged external layer of concrete. This would result in less damaged concrete located deeper in the crosssection being examined. Fig. $3 b-f$ show photographs of the tested elements surfaces. The surface roughness is visible - the longer the heating time was, the greater the damage. 


\section{EXPERIMENTAL RESULTS}

\subsection{TEMPERATURE IN THE BEAM CROSS-SECTION}

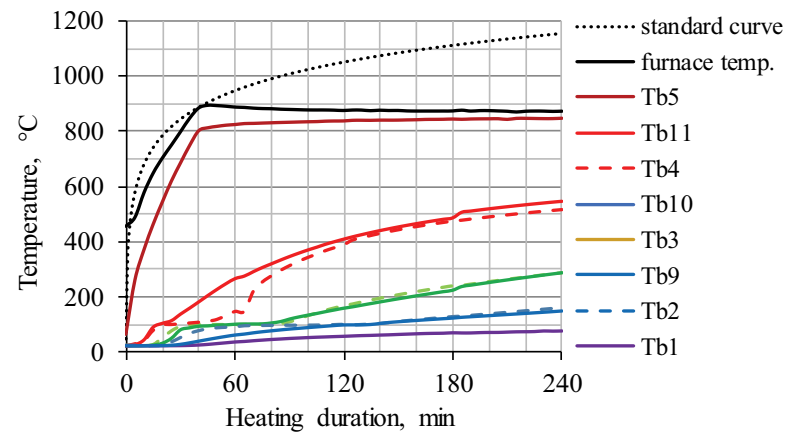

Fig. 4. Average temperature at particular points of the beam crosssection superimposed on the furnace chamber temperature and standard curve [21]

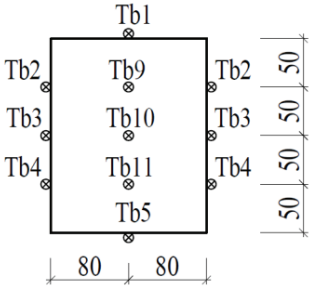

Fig. 5. Temperature measurement points in the beam cross-section

Fig. 4 presents the average values of the temperature measured at points situated inside the element cross-section and on the surface, as well as the average temperature in the furnace and, additionally, the standard curve [21]. The arrangement of measurement points is shown in Fig. 5. Average temperature values at particular points of the cross-section were determined on the basis of readings for four tested beams. In the heating time range of 0-60 $\mathrm{min}$, this is the average temperature for four beams, $60-120 \mathrm{~min}$ - three, $120-180 \mathrm{~min}$ - two, 180-240 $\mathrm{min}$ - the value measured in one beam. Moreover, the readings were averaged for measurement points located symmetrically on the lateral surfaces of the element (Fig. 5).

It can be noted that the temperature values inside the cross-section and on the surface are very similar. The obtained results indicate that the heat transfer in the elements cross-section was indeed one-way.

\subsection{REBOUND NUMBER}

Table 1 shows the values of the rebound number on the tested beams surfaces. The average rebound numbers $\left(L_{T i}\right)$ have been calculated for 10 readings at each of the three test locations on the heated element surface (Fig. 3). A correction factor due to the reading on the reference anvil differing from the nominal value $\left(L_{n o m} / L_{A, a v .}=80 / 73.6=1.09\right)$ and correction [26] for the vertical test direction (hammer striking down) have been taken into account. Based on the average rebound numbers $\left(L_{T i}\right)$ 
at the three test locations, the average rebound number $\left(L_{T}\right)$ for each element as well as standard deviation $\left(s_{L}\right)$ and coefficient of variation $\left(v_{T}\right)$ [26] were determined.

Table 1. Rebound numbers for tested beams

\begin{tabular}{|c|c|c|c|c|c|c|}
\hline Element & $\begin{array}{c}\text { Test } \\
\text { location }\end{array}$ & $\begin{array}{l}\text { Average rebound } \\
\text { number at the } \\
\text { test location } L_{T i}\end{array}$ & $\begin{array}{l}\text { Average rebound } \\
\text { number for the } \\
\text { element } L_{T}\end{array}$ & $\begin{array}{c}\text { Standard } \\
\text { deviation } s_{L}\end{array}$ & $\begin{array}{c}\text { Coefficient } \\
\text { of variation } \\
v_{L}=s_{L} / L[\%]\end{array}$ & $\begin{array}{c}\text { Relative } \\
\text { rebound number } \\
\text { reduction } L_{T} / L_{0}\end{array}$ \\
\hline \multirow{3}{*}{$\begin{array}{c}\text { B } 0 \\
\text { unheated } \\
(\mathrm{T}=0 \mathrm{~min})\end{array}$} & $\mathrm{B} 0_{1}$ & 48.6 & \multirow{3}{*}{49.0} & \multirow{3}{*}{1.1} & \multirow{3}{*}{$2.2 \%$} & \multirow{3}{*}{1.00} \\
\hline & $\mathrm{B} 0_{2}$ & 48.2 & & & & \\
\hline & $\mathrm{B}_{3}$ & 50.2 & & & & \\
\hline \multirow{3}{*}{$\begin{array}{c}\text { B I } \\
(\mathrm{T}=60 \mathrm{~min})\end{array}$} & $\mathrm{BI}_{1}$ & 46.5 & \multirow{3}{*}{46.4} & \multirow{3}{*}{1.3} & \multirow{3}{*}{$2.9 \%$} & \multirow{3}{*}{0.83} \\
\hline & $\mathrm{BI}_{2}$ & 47.7 & & & & \\
\hline & $\mathrm{BI}_{3}$ & 45.0 & & & & \\
\hline \multirow{3}{*}{$\begin{array}{c}\text { B II } \\
(\mathrm{T}=120 \mathrm{~min})\end{array}$} & $\mathrm{BII}_{1}$ & 38.9 & \multirow{3}{*}{38.0} & \multirow{3}{*}{0.9} & \multirow{3}{*}{$2.3 \%$} & \multirow{3}{*}{0.50} \\
\hline & $\mathrm{BII}_{2}$ & 37.2 & & & & \\
\hline & $\mathrm{BII}_{3}$ & 37.9 & & & & \\
\hline \multirow{3}{*}{$\begin{array}{c}\text { B III } \\
(\mathrm{T}=180 \mathrm{~min})\end{array}$} & $\mathrm{BIII}_{1}$ & 34.1 & \multirow{3}{*}{34.2} & \multirow{3}{*}{1.3} & \multirow{3}{*}{$3.7 \%$} & \multirow{3}{*}{0.38} \\
\hline & $\mathrm{BIII}_{2}$ & 33.0 & & & & \\
\hline & $\mathrm{BIII}_{3}$ & 35.5 & & & & \\
\hline \multirow{3}{*}{$\begin{array}{c}\text { B IV } \\
(\mathrm{T}=240 \mathrm{~min})\end{array}$} & $\mathrm{BIV}_{1}$ & 29.0 & \multirow{3}{*}{30.0} & \multirow{3}{*}{1.7} & \multirow{3}{*}{$5.7 \%$} & \multirow{3}{*}{0.26} \\
\hline & $\mathrm{BIV}_{2}$ & 31.9 & & & & \\
\hline & $\mathrm{BIV}_{3}$ & 29.0 & & & & \\
\hline
\end{tabular}

For all beams, low values of rebound number coefficient of variation $\left(v_{T}<7 \%\right)$ were obtained. This allows evaluating the uniformity of concrete in the near-surface layer as very good [26].

It should also be noted that the examination of the rough surface of heated elements did not cause a large scatter of results. This leads to a conclusion that in order to simplify the measurements in many locations of a structure after a fire, it is possible to abandon the time-consuming grinding of the tested surface. This does not have a significant impact on the rebound number readings taken during the preliminary concrete assessment.

The rebound number decreases as the heating duration increases, i.e. with the progressing degradation of concrete in the near-surface layer. For the beam heated for 60 minutes, a slight reduction of the rebound number was observed $\left(L_{T} / L_{0}=0.83\right)$. In the case of the beam exposed to high temperature for 240 minutes, the rebound number decreased very significantly $\left(L_{T} / L_{0}=0.26\right)$. 


\section{DISCUSSION OF TEST RESULTS}

\subsection{COMPARISON OF TEMPERATURE MEASUREMENT RESULTS WITH TEMPERATURE FIELD CALCULATED USING THE FINITE ELEMENT METHOD}

In order to obtain complete information about the temperature field in the element cross-section in relation to the heating duration, FEM calculations were performed using the SAFIR software [29]. The results were compared with the temperature values obtained at particular measurement points during heating the beams.

The calculations were based on a two-dimensional model of a beam cross-section of $160 \times 200 \mathrm{~mm}$, with an orthogonal grid of four-node finite elements of $10 \mathrm{~mm}$ side. The boundary conditions were determined according to which heat penetrated into the cross-section only from the bottom. A temperature corresponding to that measured at point $\mathrm{Tb} 5$ (see Fig. 5) at the beams underside was set for the entire bottom edge of the cross-section. In this way, the effect of radiation in the furnace chamber on the heated surface of the element, which is difficult to estimate, was eliminated. Thermal properties of concrete: specific heat and thermal conductivity were adopted in accordance with [21]. In the model, the presence of reinforcing bars was also taken into account, as specified in the reinforcement scheme of tested elements (Fig. 1).

Fig. 6 shows a comparison of FEM calculation results with experimental results. As mentioned above (Fig. 4), the temperature values measured inside the cross-section of the tested element and on the lateral surfaces were practically identical (a one-way heat transfer). For this reason, the readings at the measurement points located in the central part of the cross-section (Tb5, Tb11, Tb10, Tb9, Tb1; see Fig. 5) were used for comparison with the results of calculations.

Good compatibility of the experimental and calculated results was obtained. Therefore, it can be concluded that the assumption according to which the temperature at the bottom edge of the FEM model was equal to that measured at the beam underside provided reliable calculation results.

Fig. 7 presents the isotherm layout (calculated) in the beam cross-section after the specified heating time. The black solid line indicates the position of the isotherm $500^{\circ} \mathrm{C}$. The distance of this line from the bottom edge of the cross-section can be identified with the thickness of the damaged concrete layer.

In the obtained temperature fields there are visible slight irregularities in the horizontal isotherm layout, appearing in the location of reinforcing bars (due to the different thermal conductivity of concrete and steel). Generally, however, it can be assumed that a one-way heat transfer occurred in the cross-section. 
Fig. 8 shows diagrams of temperature in the beam cross-section, depending on the distance from the bottom edge and on the heating duration. Additionally, the dashed lines indicate the position of the isotherm $500^{\circ} \mathrm{C}$.

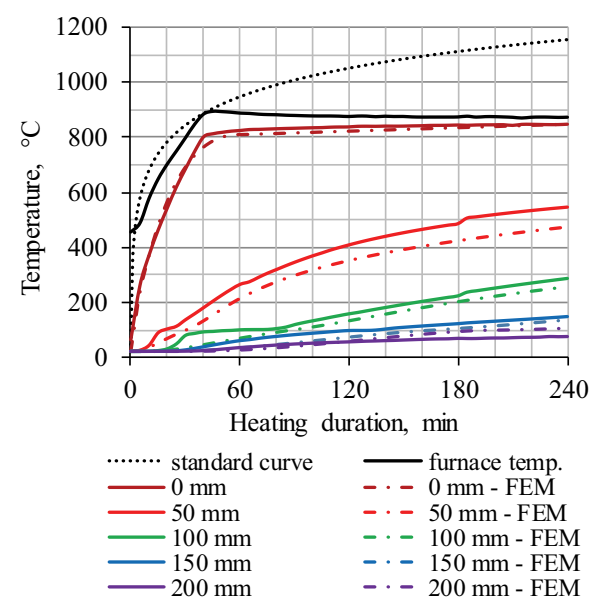

Fig. 6. Comparison of the values of temperature in the beam cross-section obtained in experimental tests and in the FEM model
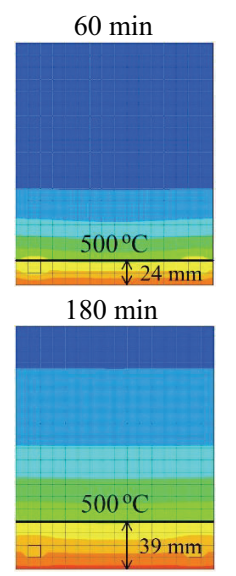

$120 \mathrm{~min}$

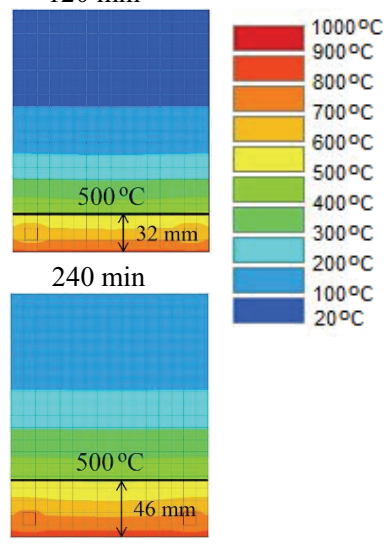

Fig. 7. Isotherm layout in the element cross-section after a specified heating time

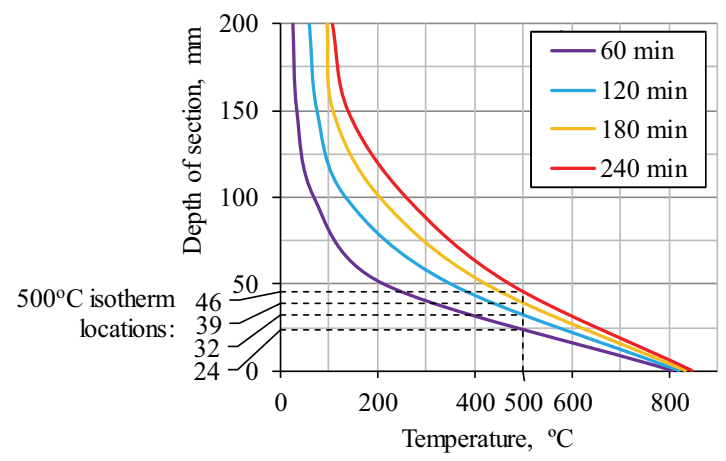

Fig. 8. Temperature in the beam cross-section for a specified heating time

\subsection{RELATIONSHIP BETWEEN THE REBOUND NUMBER REDUCTION AND THE DECREASE OF CONCRETE COMPRESSIVE STRENGTH IN THE NEAR-SURFACE LAYER}

In order to examine how the rebound number reflects concrete damage, Fig. 9 and 10 compare the relative decrease of the rebound number $\left(L_{T} / L_{0}\right.$; Table 1) with the relative reduction of the compressive strength $\left(f_{c \theta} / f_{c k}\right)$ of concrete at high temperature. The Eurocode model [21], which can 
be considered reliable [2, 3, 22], was used to determine this reduction. The decrease of compressive strength of concrete with siliceous aggregate (such aggregate was used in the concrete of tested beams) at high temperature is shown in Fig. 10. On the basis of this relationship and the temperature distribution in the beam cross-section after a specified heating time (Fig. 8), the relative strength decrease of concrete at a distance: 10, 15, 20 and $30 \mathrm{~mm}$ from the bottom cross-section edge (see Table 2) was calculated.

Table 2. Temperature and relative reduction of concrete compressive strength in the heated element for different depths of the cross-section

\begin{tabular}{|c|c|c|c|c|c|c|c|c|c|}
\hline \multirow{2}{*}{$T[\mathrm{~min}]$} & \multirow{2}{*}{$L_{T} / L_{0}$} & \multicolumn{9}{|c|}{ Distance from the surface $[\mathrm{mm}]$} \\
\cline { 3 - 11 } & & \multicolumn{2}{|c|}{10} & \multicolumn{2}{|c|}{15} & \multicolumn{2}{|c|}{20} & \multicolumn{2}{c|}{30} \\
\cline { 3 - 11 } & & $\theta\left[{ }^{\circ} \mathrm{C}\right]$ & $f_{c \theta} / f_{c k}$ & $\theta\left[{ }^{\circ} \mathrm{C}\right]$ & $f_{c \theta} / f_{c k}$ & $\theta\left[{ }^{\circ} \mathrm{C}\right]$ & $f_{c \theta} / f_{c k}$ & $\theta\left[{ }^{\circ} \mathrm{C}\right]$ & $f_{c \theta} / f_{c k}$ \\
\hline 0 & 1.00 & 22 & 1.00 & 22 & 1.00 & 22 & 1.00 & 22 & 1.00 \\
\hline 60 & 0.83 & 459 & 0.66 & 384 & 0.76 & 309 & 0.84 & 205 & 0.94 \\
\hline 120 & 0.50 & 623 & 0.41 & 551 & 0.52 & 480 & 0.63 & 369 & 0.78 \\
\hline 180 & 0.38 & 694 & 0.31 & 640 & 0.39 & 586 & 0.47 & 495 & 0.60 \\
\hline 240 & 0.26 & 753 & 0.22 & 711 & 0.28 & 670 & 0.34 & 596 & 0.45 \\
\hline
\end{tabular}

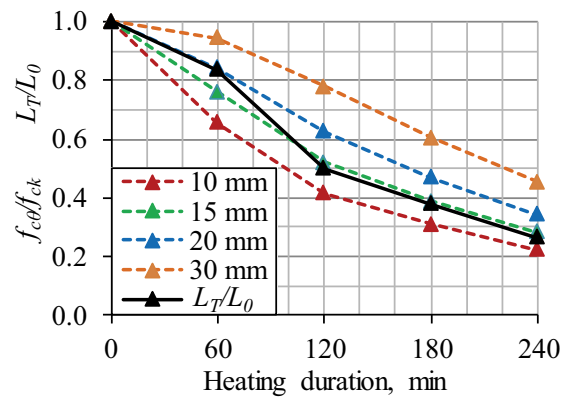

Fig. 9. Relative decrease of concrete compressive strength at subsequent depths of the cross-section (dashed lines) and relative rebound number reduction depending on heating time (continuous line)

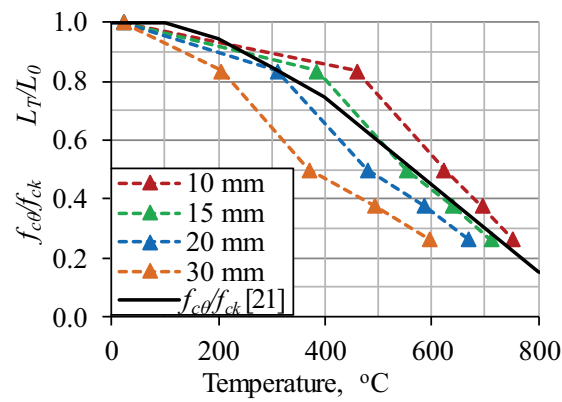

Fig. 10. Relative rebound number reduction depending on the temperature at subsequent depths of the cross-section (dashed lines) and relative decrease of concrete compressive strength [21] (continuous line)

Fig. 9 compares the compressive strength decrease $\left(f_{c \theta} / f_{c k}\right)$ of concrete at particular depths of the cross-section with the rebound number reduction $\left(L_{T} / L_{0}\right)$ obtained in the tests, against the heating duration. Additionally, Fig. 10 shows the same values of $f_{c \theta} / f_{c k}$ and $L_{T} / L_{0}$ in a different coordinate system, i.e. depending on the concrete temperature. The rebound number diagrams were obtained by joining points whose $\mathrm{x}$-coordinate was the temperature at considered depth in the cross-section after 
a specified heating time, and y-coordinate - the relative decrease of the rebound number after that time.

In both Figures (Fig. 9 and Fig. 10) it can be observed that the rebound number decreases with increasing heating duration, and $L_{T} / L_{0}$ values reflect most accurately the relative compressive strength reduction $\left(f_{c \theta} / f_{c k}\right)$ of concrete situated $15 \mathrm{~mm}$ from the bottom edge of the cross-section. This distance corresponds to the centre of the near-surface layer (30 mm thick) which is measured with a sclerometer [24].

Therefore, it can be concluded that the sclerometric method can be used for the preliminary comparative assessment of concrete in the external cross-section layer of a structural element after a fire. In the case when the effect of high temperature in the cross-section is significant, the concrete at the surface is destroyed and cavities occur. This enables adjacent, deeper layers of concrete to be examined with a Schmidt hammer. However, it is not possible to estimate the strength of concrete more distant from the element surface, i.e. one to which there is no direct access with the sclerometer.

\section{SUMMARY AND CONCLUSIONS}

The paper presents a description and results of an experimental study focused on the applicability of the sclerometric method to the preliminary assessment of concrete in the near-surface layer of the cross-section of RC structural elements after fire. Tests were performed on beams heated from the bottom in a controlled way, which was to ensure a one-way heat transfer in the cross-section.

A significant decrease of the rebound number depending on the heating duration was observed. For the beam exposed to high temperature for the shortest time $(60 \mathrm{~min})$, the rebound number was reduced by only $17 \%\left(L_{T} / L_{0}=0.83\right)$. In this case the thickness of the damaged concrete layer, defined approximately as corresponding to the distance of isotherm $500^{\circ} \mathrm{C}$ from the heated element surface, was about $24 \mathrm{~mm}$. For the beam heated for the longest time $(240 \mathrm{~min})$ the rebound number decreased significantly - by $74 \%\left(L_{T} / L_{0}=0.26\right)$. In this case the thickness of the degraded concrete layer was equal to about $46 \mathrm{~mm}$.

Comparison of the rebound number variability depending on the heating duration with the decrease of concrete compressive strength $\left(f_{c \theta} / f_{c k}\right)$, determined on the basis of the Eurocode model [21] and concrete temperature in the element cross-section, indicates that the relative rebound number reduction $\left(L_{T} / L_{0}\right)$ well corresponds to the relative strength decrease $\left(f_{c \theta} / f_{c k}\right)$ of concrete situated at the depth of $15 \mathrm{~mm}$ from the heated cross-section edge. This distance is approximately equal to half of the thickness of the near-surface layer measured with a sclerometer (30 mm; [24]). 
The obtained results confirm that the sclerometric method can be used for the preliminary assessment of the concrete quality in the near-surface layer of elements in structures after a fire. This assessment can be performed in order to identify areas where the concrete: (1) has been completely destroyed, (2) has been only slightly damaged, or (3) has not been significantly affected by heat and is not damaged.

In practice, in order to simplify the preliminary assessing of structures after fire using a sclerometer, it is possible to abandon the time-consuming grinding of the element surface (which is recommended for testing at ordinary room temperature). In the presented study, the beams surfaces exposed to high temperature were not grinded. Neertheless, small scatter of obtained results was observed.

\section{REFERENCES}

1. fib Bulletin 38/2007, "Fire design for concrete structures - materials, structures and modelling. State-of-art report", International Federation for Structural Concrete (fib), p. 97, 2007.

2. V. R. Kodur, "Properties of concrete at elevated temperature", ISRN Civil Engineering 2014: 1-15, 2014. DOI: $10.1155 / 2014 / 468510$

3. R. Kowalski, "Mechanical properties of concrete subjected to high temperature", Architecture Civil Engineering Environment 3(2): 61-70, 2010.

4. R. Kowalski, "The effects of the cooling rate on the residual properties of heated-up concrete", Structural Concrete. Journal of the fib 8(1): 11-15, 2007. DOI: 10.1680/stco.2007.8.1.11

5. M. Abramowicz, R. Kowalski, "The Influence of Short Time Water Cooling on the Mechanical Properties of Concrete Heated up to High Temperature", Journal of Civil Engineering and Management 11(2): 85-90, 2005. DOI: $10.1080 / 13923730.2005 .9636336$

6. W. Jackiewicz-Rek, T. Drzymała, A. Kuś, M. Tomaszewski, "Durability of High Performance Concrete (HPC) Subject to Fire Temperature Impact”. Archives of Civil Engineering, 62(4): 73-94, 2016. DOI: $10.1515 /$ ace-2015-0109

7. K. Kordina, "Design of concrete buildings for fire resistance", Chapter 6 in: Structural Concrete. Textbook on behaviour, design and performance. Second edition. Vol. 4. fib Bulletin 54: 1-36, 2010.

8. R. Kowalski, P. Król, "Experimental Examination of Residual Load Bearing Capacity of RC Beams Heated up to High Temperature", Sixth International Conference Structures in Fire, Michigan State University, East Lansing, Michigan, USA, Proceedings edited by V. K. R. Kodur and J. M. Fransen, DEStech Publications Inc., pp 254-261, 2010.

9. R. Kowalski, "Temperature distribution in R/C cross-section subjected to heating and then freely cooled down in air", Chapter 9 in: Benchmark Studies. Experimental Validation of Numerical Models in Fire Engineering, CTU Publishing House, Czech Technical University in Prague, pp 107-122, 2014.

10. Z. P. Bažant, M. F. Kaplan, "Concrete at High Temperatures. Material Properties and Mathematical Models", Harlow, Essex. Longman, 1996.

11. G. A. Khoury, "Compressive strength of concrete at high temperatures: a reassessment”, Magazine of Concrete Research 44(161): 291-309, 1992. DOI: 10.1680/macr.1992.44.161.291

12. P. Marti, "Limit analysis and design of concrete and masonry structures", Archives of Civil Engineering 52(2): 351-366, 2006.

13. L. X. Xiong, "Uniaxial dynamic mechanical properties of tunnel lining concrete under moderate-low strain rate after high temperature", Archives of Civil Engineering 61(2): 35-52, 2015. DOI: 10.1515/ace-2015-0013

14. J. Wróblewska, R. Kowalski, M. Abramowicz, „Factors and phenomena affecting the strength of concrete in structures after fire", Materiały Budowlane 539(7): 11-12, 2017 (in Polish). DOI: 10.15199/33.2017.07.04

15. M. S. Abrams, "Compressive Strength of Concrete at Temperatures to 1600 F", ACI Publication SP25, paper SP25-2, pp 33-58, 1971.

16. I. Hager, T. Tracz, "The Impact of the Amount and Length of Fibrillated Polypropylene Fibres on the Properties of HPC Exposed to High Temperature", Archives of Civil Engineering 56(1): 57-68, 2010. DOI: $10.2478 /$ v.10169-010-0003-z 
17. G. A. Khoury, C. E. Majorana, F. Pesavento, B. A. Schrefler, "Modelling of Heated Concrete", Magazine of Concrete Research 54(2): 77-101. 2002. DOI: 10.1680/macr.54.2.77.40895

18. U. Schneider, "Behaviour of Concrete under Thermal Steady State and Non-Steady State Conditions", Fire and Materials 1(3): 103-115, 1976. DOI: 10.1002/fam.810010305

19. RILEM TC 129-MHT, "Test methods for mechanical properties of concrete at high temperatures", Part 1: Introduction, Part 2: Stress-strain relation, Part 3: Compressive strength for service and accident conditions, Materials and Structures 28(181): 410-414, 1995.

20. U. Schneider, "Concrete at High Temperatures - A General Review", Fire Safety Journal 13(1): 55-68, 1988. DOI: $10.1016 / 0379-7112(88) 90033-1$

21. EN 1992-1-2:2004. Eurocode 2: Design of concrete structures - Part 1-2: General rules - Structural fire design.

22. R. Kowalski, "Calculations of reinforced concrete structures fire resistance", Architecture Civil Engineering Environment. Journal of the Silesian University of Technology 2(4): 61-69, 2009.

23. I. Hager, "Methods for assessing the state of concrete in fire damaged structures", Cement Wapno Beton 4: $167-$ 178, 2009.

24. E. Annerel, L. Taerwe, "Techniques for the evaluation of concrete structures after fire”, International Conference Application of Structural Fire Engineering, Prague, Czech Republic, pp. 92-96, 2011.

25. EN 12504-2:2. Testing concrete in structures - Part 2: Non-destructive testing - Determination of rebound number.

26. ITB Manual 210/1977, "Manual for using Schmidt hammers for non-destructive concrete quality control", Warsaw, ITB, 1977 (in Polish).

27. EN 13791:2007. Assessment of in-situ compressive strength in structures and pre-cast concrete components.

28. J. Wróblewska, R. Kowalski, M. Abramowicz, "Non-destructive methods of the assessment of concrete in structure after fire", Materiały Budowlane 544(12): 74-75, 2017 (in Polish). DOI:10.15199/33.2017.12.22

29. J. Franssen, "User's Manual for SAFIR 2011 A Computer Program for Analysis of Structures Subjected to Fire", University of Liege, Belgium, 2011.

\section{LIST OF FIGURES AND TABLES:}

Fig. 1. Beams dimensions and reinforcement

Rys. 1. Wymiary i zbrojenie belek

Fig. 2. Beam location in the furnace chamber

Rys. 2. Usytuowanie belki w komorze pieca

Fig. 3. Tested elements: a) sclerometric test locations, b-f) surface of the beam underside after a specified heating time

Rys. 3. Badane elementy: a) lokalizacja miejsc pomiarowych w badaniu sklerometrem, b-f) powierzchnia spodu belki po założonym czasie ogrzewania

Fig. 4. Average temperature at particular points of the beam cross-section superimposed on the furnace chamber temperature and standard curve [21]

Rys. 4. Średnia temperatura w wyznaczonych punktach przekroju na tle temperatury w piecu i krzywej standardowej wg [21]

Fig. 5. Temperature measurement points in the beam cross-section

Rys. 5. Układ punktów pomiaru temperatury w przekrojach belki

Fig. 6. Comparison of the values of temperature in the beam cross-section obtained in experimental tests and in the FEM model

Rys. 6. Porównanie temperatury w przekroju belki otrzymanej w badaniach eksperymentalnych oraz w modelu MES

Fig. 7. Isotherm layout in the element cross-section after a specified heating time 
Rys. 7. Położenie izoterm w przekroju belki po określonym czasie ogrzewania

Fig. 8. Temperature in the beam cross-section for a specified heating time

Rys. 8. Temperatura w przekroju belki dla różnego czasu ogrzewania

Fig. 9. Relative decrease of concrete compressive strength at subsequent depths of the cross-section (dashed lines) and relative rebound number reduction depending on heating time (continuous line)

Rys. 9. Względna redukcja wytrzymałości betonu na ściskanie na kolejnych głębokościach w przekroju (linie przerywane) oraz względne zmniejszenie liczby odbicia w zależności od czasu ogrzewania (linia ciągła)

Fig. 10. Relative rebound number reduction depending on the temperature at subsequent depths of the crosssection (dashed lines) and relative decrease of concrete compressive strength [21] (continuous line)

Rys. 10. Względne zmniejszenie liczby odbicia w zależności od temperatury na kolejnych głębokościach w przekroju (linie przerywane) oraz względna redukcja wytrzymałości betonu na ściskanie [21] (linia ciągła) Tab. 1. Rebound numbers for tested beams

Tab. 1. Liczba odbicia dla badanych belek

Tab. 2. Temperature and relative reduction of concrete compressive strength in the heated element for different depths of the cross-section

Tab. 2. Temperatura i względne zmniejszenie wytrzymałości na ściskanie betonu w ogrzewanym elemencie dla różnej głębokości w przekroju 


\section{WYKORZYSTANIE SKLEROMETRU DO WSTĘPNEJ OCENY JAKOŚCI BETONU W KONSTRUKCJACH PO POŻARZE}

Słowa kluczowe: beton, wysoka temperatura, pożar, badanie nieniszczące, sklerometr, młotek Schmidta, liczba odbicia

\section{STRESZCZENIE}

W artykule przedstawiono opis i wyniki badań mających na celu sprawdzenie przydatności metody sklerometrycznej do wstępnej oceny jakości betonu w konstrukcjach po pożarze.

Jednym z najistotniejszych zjawisk wpływających na nośność konstrukcji narażonej na warunki pożarowe jest obniżenie wytrzymałości betonu w wysokiej temperaturze w wyniku procesów fizyko-chemicznych i uszkodzeń mechanicznych zachodzących wjego strukturze. Ze względu na dużą bezwładność termiczną, beton przestaje mieć jednorodne właściwości w przekroju ogrzewanego elementu, a największa degradacja betonu zachodzi w strefie przypowierzchniowej. Podczas oceny konstrukcji po pożarze szczególnie istotne jest określenie grubości zewnętrznej warstwy przekroju elementu, w której beton jest na tyle uszkodzony, że należy go uznać za zniszczony. Z praktycznego punktu widzenia rozpatrywania nośności konstrukcji można przyjąć, że grubość tej warstwy odpowiada odległości izotermy $500^{\circ} \mathrm{C}$ od ogrzewanej krawędzi przekroju.

Metoda sklerometryczna jest przeznaczona do nieniszczących badań betonu in situ i w zwykłych warunkach pozwala na pośrednie oszacowanie wytrzymałości betonu na ściskanie na podstawie mierzonej liczby odbicia (zależnej od twardości powierzchniowej betonu). Grubość przypowierzchniowej warstwy przekroju badanego elementu, jaką obejmuje zasięg pomiaru sklerometrem (młotkiem Schmidta), wynosi do $30 \mathrm{~mm}$.

W celu stwierdzenia przydatności metody sklerometrycznej do wstępnej oceny betonu po pożarze, przeprowadzono badanie elementów żelbetowych ogrzewanych w sposób zaplanowany, a następnie swobodnie wystudzonych na powietrzu. Zbadano cztery belki żelbetowe poddane działaniu wysokiej temperatury z jednej strony (od spodu) przez 60 , 120, 180 i 240 minut oraz jedną belkę nieogrzewaną. Boczne powierzchnie elementów zostały zaizolowane termicznie, dzięki czemu zagwarantowano jednokierunkowy przepływ ciepła w przekroju. Wartości temperatury mierzonej w środku przekroju oraz na jego bocznej krawędzi były bardzo zbliżone.

W celu uzyskania pełnej informacji o polu temperatury w przekroju elementu w zależności od czasu ogrzewania, przeprowadzono obliczenia MES za pomocą programu komputerowego SAFIR. Na całej dolnej krawędzi zamodelowanego przekroju zadano temperaturę odpowiadającą temperaturze mierzonej na spodzie belek. W ten sposób wyeliminowano trudne do oszacowania określenie wpływu promieniowania w komorze pieca na ogrzewaną powierzchnię elementu. Otrzymano dobrą zgodność pomiarów temperatury w przekroju z wartościami obliczonymi.

Po ostudzeniu elementy obrócono spodem do góry, zapewniając w ten sposób dobry dostęp do powierzchni ogrzewanej. Dla każdej belki dokonano po dziesięć odczytów liczby odbicia w trzech miejscach pomiarowych, a następnie wyznaczono jej średnią wartość. Zaobserwowano znaczne zmniejszenie liczby odbicia w zależności od czasu ogrzewania elementów. W przypadku belki poddanej działaniu wysokiej temperatury przez 60 minut (najkrótszy rejestrowany czas), liczba odbicia uległa zmniejszyła się zaledwie o $17 \%\left(L_{T} / L_{0}=0,83\right)$. Grubość zniszczonej warstwy betonu, określona w przybliżeniu jako odpowiadająca odległości izotermy $500^{\circ} \mathrm{C}$ od powierzchni ogrzewanej, wyniosła w tym przypadku 24 mm. W belce ogrzewanej przez 240 minut (najdłużej) liczba odbicia zmniejszyła się aż o $74 \%\left(L_{T} / L_{0}=0,26\right)$, przy grubości zdegradowanej warstwy betonu równej $46 \mathrm{~mm}$. 
W praktyce, w celu uproszczenia wstępnych badań konstrukcji po pożarze za pomocą sklerometru, można zrezygnować z kłopotliwego szlifowania powierzchni elementów (co jest zalecane do badań w zwykłej temperaturze). W przedstawionym badaniu nie oszlifowano powierzchni belek narażonej na działanie wysokiej temperatury, a mimo tego otrzymano małe rozrzuty wyników.

Zmienność liczby odbicia w zależności od czasu ogrzewania porównano ze względną redukcją wytrzymałości betonu na ściskanie $\left(f_{c \theta} / f_{c k}\right)$ określoną na podstawie modelu eurokodowego i temperatury w przekroju elementu. Stwierdzono, że względne zmniejszenie liczby odbicia $\left(L_{T} / L_{0}\right)$ najbardziej odpowiada względnemu obniżeniu wytrzymałości na ściskanie $\left(f_{c o} / f_{c k}\right)$ betonu znajdującego się w odległości $15 \mathrm{~mm}$ od dolnej krawędzi przekroju, a więc w środku warstwy objętej zasięgiem pomiaru sklerometrem $(30 \mathrm{~mm})$.

Otrzymane wyniki potwierdzają, że metoda sklerometryczna może być stosowana do wstępnej oceny jakości betonu w warstwie przypowierzchniowej elementów w konstrukcji po pożarze. Ocena taka może być przydatna do wytypowania miejsc, w których beton: (1) został zniszczony, (2) jest uszkodzony w niewielkim stopniu lub (3) nie był poddany istotnemu wpływowi wysokiej temperatury i w ogóle nie został uszkodzony. Za pomocą sklerometru nie jest natomiast możliwe oszacowanie wytrzymałości na ściskanie betonu znajdującego się w głębi przekroju elementu, poza warstwą zewnętrzną. 